\title{
A History of the Modern Middle East, 4th ed.
}

William L. Cleveland and Martin Bunton

Boulder: Westview Press, 2009. 618 pages.

This extensive and lucid book provides a laudable introduction to the political history of the Middle East, tracing its development from Islam's rise in the seventh century to the recent direct American military involvement in Iraq and Afghanistan. While the opening chapters start with Islam's "rise and expansion," however, the book's main chronological focus centers on the late eighteenth century onward. This only adds to its current status. The geographical area covered is from Egypt to Iran, and from Turkey to the Arabian Peninsula. Some omission, however, was necessary (e.g., western North Africa, Sudan, and Afghanistan) in order to keep the book manageable (p. xiii). While extensiveness and generality frequently lead to unavoidable simplification and superficiality, this book nevertheless contains an insightful analysis of the continuum of events and transformations that have helped shape the region's history and geography. The authors are to be praised for their grasp and clear conceptualization of core issues, as well as for their effort to maintain a good measure of narrative neutrality and thus eschewing the usual prejudices and biases.

The book consists of five parts incorporating twenty-five chapters. Part 1 (three chapters) focuses on Islam's rise, expansion, and the patterns it set until the eighteenth century. The survey does not go deeply into these matters, however, but rather focuses on Islamic civilization's global aspects based on different centers of Islamic florescence instead of dynastic histo- 
ries (p. xiv). Part 2 (six chapters) looks at what Cleveland and Bunton term the three main centers of "political authority": the Ottoman Empire, the autonomous province of Egypt, and the Qajar dynasty of Iran in both the nineteenth and early twentieth (1920; post-WWI and the collapse of the Ottoman Empire) centuries. They trace each one's similarities and their different historical trajectories.

Their approach is seen in some of the concepts introduced to challenge conventional understandings of that period's events. Cleveland and Bunton recognize the "wrenching" and "disorienting" experience of the Muslim world that, for the first time in its history, found itself without a form of galvanizing caliphate and most of its land under external non-Muslim encroachment and subsequent European colonialism and domination. Thus, instead of using terms such as modernization or westernization to describe Muslim responses to the challenges of a modern world, the authors utilize the term transformation as a better designation of the ensuing process of change in the Ottoman Empire and other parts of the Islamic world (p. xiv).

Part 3 (four chapters), which covers the period between the post-WWI mandate system and the creation of Israel, focuses on the emergence of new Arab states from the rubble of the collapsed Ottoman Empire. Included are attempts to identify the continuity of historical Ottoman influences as well as the impact of European (mainly British and French) imposed administrative patterns that played a determining role in their development. This part looks at the emergence of modern Turkey under Ataturk; Iran under Reza Shah; Egypt, Iraq, and Transjordan under British domination; Syria and Lebanon under French domination; the rise of Saudi Arabia under the British-supported King Abdel-Aziz; and Palestine and the creation of Israel under the mandate system. The different ideologies of regionalism, panArab nationalism, and Islamic solidarity are also discussed.

Part 4 (four chapters) takes the readers from 1945 until the early 1970s, a period largely dominated by Gamal Abdel Nasser (1954-70) and thus termed the "Nasser era." Included is a survey of Arab politics and inter-state tensions, the Arab-Israeli war of 1967, the emergence of the Palestine Liberation Organization (PLO), and Israeli politics and institutions. Also discussed is the swaying between democracy and authoritarianism in the region as a whole, but particularly with regard to Turkey (which gravitated toward some democratic form of government) and Iran (which moved toward a path of authoritarianism under the Pahlavis).

Finally, part 5 (eight chapters) examines the period between the 1970s until the present day: the 1973 Arab-Israeli war, the Egyptian-Israeli peace 
treaty, Husni Mubarak's incompetent and corrupt rule of Egypt, Syria under Hafez Assad and his son Bashar, Iraq under Saddam Hussain, the Iranian Islamic revolution of 1979, the 1987 Palestinian intifada and the ensuing Oslo agreements (1991), the impact of oil price increases on the Gulf, America's "troubled moment in the Middle East," and, finally, Iran's nuclear energy program. Regarding this last issue, despite its almost unanimous internal support, Cleveland and Bunton raise the prospect that the Iranians may question pouring too much money into alternative sources of energy (p. 575). Given Iran's high consumption of oil at subsidized prices and the fact that more may be needed for exporting as well as future contingencies, such a prospect seems unlikely.

This book, which presents quite a broad scope of the Middle East, does a commendable job in linking historical events in fluid, logical narrative sequences that help readers unfamiliar with the Middle East connect the events. I would, however, have liked to have seen the authors contest the Eurocentric term Middle East, which would have taken only a few pages, but is, in my opinion, of significant importance. After all, concepts shape perceptions. Nevertheless, this book has much to commend it and is highly recommended as an introductory text to the Arab and the Muslim worlds.

Amr G. E. Sabet Department of Public Management Vaasa University, Finland 